\title{
THE INFLUENCE OF TRANSNATIONAL CORPORATIONS ON THE CURRENT TRENDS IN THE WORLD ECONOMY
}

\author{
Tatiana Podolskaya \\ Daria Alekseeva \\ Russian Presidential Academy of Economy and Public Administration (RANEPA), \\ Rostov-on-Don, Russia
}

The article is devoted to the analysis of TNCs' influence on the current trends in the world economy - in the field of international trade, in the environmental sphere and in innovations. On the example of companies such as Apple, Volkswagen, JPMorgan Chase and others, the key trends in the sustainable development of the world economy and the most current problems of their development in the context of the COVID-19 pandemic are highlighted.

Keywords: TNC; world economy; environmental problems; sustainable development

\section{Introduction}

Nowadays the global economy is being dominated by companies that are giant in size. The workforce of such companies is calculated in thousands, and their revenue is the subject of envy for many smaller countries since it often exceeds their annual GDPs. Transnational corporations are an integral and very important part of the contemporary economy, as they are predetermining the key trends in its development (Popkova et al., 2017).

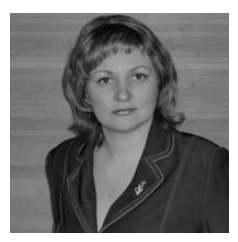

\section{Tatiana Podolskaya}

Candidate of Economic Sciences, Associate Professor, Head of Department of International Economic Relations at South Russian Institute of management of Russian Presidential Academy of Economy and Public Administration (RANEPA). The area of scientific interests includes issues of trends of modern world economy, role of transnational corporation, international financial system, as well as the problems of its regulation. Tatiana Podolskaya is the author of more than 90 scientific papers, 5 textbooks, 3 monographs.

E-mail: tv.kuraeva@mail.ru

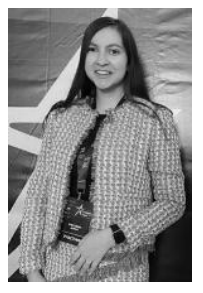

\section{Daria Alekseeva}

MBA candidate at South Russian Institute of management of Russian Presidential Academy of Economy and Public Administration (RANEPA).The area of scientific interests includes issues of trends of modern world economy, international financial system, problems of its regulation.

E-mail: d_alekseeva@mail.ru 
The very term "transnational corporation" appeared back in the late 1970s, although references to the functioning of TNCs date back to the 19th century. The very first TNCs were formed by the merger of several smaller firms and mainly specialized in the extraction of raw materials in the colonial territories of Africa, Asia and Latin America.

The beginning and the middle of the 20th century were characterized by military upheavals that served as the starting point for the creation of numerous TNCs. In 1940 there were about 300 large corporations in the world, and in the 1970s, when the economies of many states across the world began to stabilize, a new wave of mergers and acquisitions began, caused by the growing competition and the desire of many enterprises to gain leading positions at the international market (Bodienkova et al., 2017). At the end of the millennium, there were already almost 60,000 TNCs with more than 500,000 of branches in the world.

The 21 st century has truly become the era of transnationalization since the number of TNCs, in less than 20 years, has increased by another third. As of 2019, there were 82,000 multinational companies with 810,000 branches worldwide.

At the same time, there is a significant unevenness in the geographical distribution of TNC headquarters. Historically, it was the developed states that were the jurisdictions where transnationalized businesses were initially established. As a result, such developed countries as the USA (18\%), Great Britain (15\%), France (15\%), Germany (13\%) and Japan (9\%) continue to be the leaders in the number of TNCs. At the same time, transnationalized business of China is already a significant competitor to TNCs from developed countries. Of the top 100 economic subsystems today, 52 are transnational companies. Also, the share of TNCs accounts for up to $50 \%$ of the global trade and $80 \%$ of 750,000 patents issued every year (Kościelniak et al., 2017). TNCs also control certain commodity markets: $90 \%$ of the world wheat and coffee markets, $85 \%$ of the copper and bauxite markets, $80 \%$ of the tea and tin markets, and $75 \%$ of the crude oil market.

\section{Main focus of the study}

The ongoing rapid development of transnational corporations is taking place due to a number of advantages that they have over local and smaller companies (Čech, 2011).

First of all, it is all about the access to natural resources, capital and R\&D results around the world. Secondly, TNCs are offering the effect of the economies of scale in production, economic stability and financial sustainability through diversification of their business activities.

Realizing their advantages globally, transnational corporations have an ever-growing influence on the economy of separate states (Zolochevskaya et al., 2018). With their enormous financial power and influential political support, the largest corporations can dictate conditions not only to competitors, but also to entire states (governments). In particular, some of the developing countries today are forced to maintain relatively low environmental standards in the struggle to attract capital from foreign TNCs to their jurisdictions.

As a result, in recent years, the problem of ecology has attracted special attention. TNCs tend to locate their dirty production in those countries where low environmental standards continue to persist, because such neglect of environmental concerns provide competitive advantages to local economy and local population. Otherwise, environmental 


\section{THE INFLUENCE OF TRANSNATIONAL CORPORATIONS}

degradation as a payment for economic development affects not only the inhabitants of these countries, but also the ecosystem of the planet as a whole.

In 2020, for the first time since the very first annual report on global risks published by the World Economic Forum, all top 5 most likely risks threatening the planet in the next ten years, according to experts, are related to the environment. So, among the main security risks, the experts named extreme weather events that lead to the death of people and material damages, some of which are provoked by the activities of TNCs that are damaging the planet's ecosystem. It is also the failure of the climate change mitigation policies pursued by individual governments and large corporations. Also, the experts mentioned the anthropogenic damage to the environment and environmental crimes, loss of biodiversity and destruction of ecosystems, as well as major natural disasters - earthquakes, tsunamis, volcanic eruptions and geomagnetic storms (Global Risks, 2020). In other words, four of the top five risks identified by the experts are produced by transnationalized businesses.

In general, the activities of transnational corporations and international trade lead to changes in the environment through structural, scale, technological and product effects. Today, there is no common understanding of eco-social responsibility in the world, and this significantly complicates the implementation and further development of international industrial cooperation and also complicates the implementation of the 17 UN Sustainable Development Goals until 2030 (UNIDO, 2020).

Transnational corporations, having become full-fledged and active subjects of international economic relations, serve a necessary link in the process of increasing global labor productivity and raising the standards of living for all people around the planet.

In this article, studying the cases of the world-famous large market players, we will consider their influence on the formation of contemporary trends and their role in the development of the world economy.

There are several annual authoritative ratings of the world companies. Forbes 2000 is a list of 2000 largest public companies in the world, which are ranked according to four indicators: revenue, net income, assets (reported for the last 12 months) and market capitalization of companies, all according to the US-based magazine Forbes. The arithmetic mean of the four such global rankings is chosen as our integral indicator, according to which the companies are placed in the final ranking.

The statistics below are interesting to compare with those of previous years, since 2020 has been characterized by its instability against the backdrop of the worldwide COVID-19 pandemic. Many companies have lost their rankings and multibillion-dollar revenues. For example, the American Airlines back in 2019 was ranked 372nd, and at the end of the first quarter of 2020 it already dropped down to being 967 th.

However, not all transnational corporations have experienced such negative effects. Major e-commerce players such as Amazon, Alibaba and Walmart have seen growth thanks to increased online purchases volumes. Remote conferencing company Zoom and enterprise messenger Slack have also benefited greatly from the realities of working from home. In 2020 both these companies have joined the list of most successful companies in the world.

The financial sector has seen relative stability, with the Industrial and Commercial Bank of China staying in the first place for the eighth consecutive years, with its more than $\$$ 4.3 trln in assets.

Fortune Global 1000 is the rating of 1000 largest world companies, the key criterion in which is the company's revenue. The list is compiled and published annually by the 
American business magazine Fortune. Also, since 1955, the same magazine has been publishing the Fortune Global 500 sub-list.

Table 1 - Top of Forbes 2000, Q1 of 2020

(Source: Forbes Global, 2000)

\begin{tabular}{|c|c|c|c|c|c|c|}
\hline Rank & Company & $\begin{array}{l}\text { Country / } \\
\text { Territory }\end{array}$ & Sales & Profits & Assets & $\begin{array}{l}\text { Market } \\
\text { Value }\end{array}$ \\
\hline 1 & ICBC & China & \$177.2 B & $\$ 45.3 \mathrm{~B}$ & $\$ 4,322.5 \mathrm{~B}$ & \$242.3 B \\
\hline 2 & China Construction Bank & China & \$162.1 B & $\$ 38.9 \mathrm{~B}$ & $\$ 3,822 \mathrm{~B}$ & $\$ 203.8 \mathrm{~B}$ \\
\hline 3 & JPMorgan Chase & United States & \$ $142.9 \mathrm{~B}$ & $\$ 30 \mathrm{~B}$ & $\$ 3,139.4 \mathrm{~B}$ & \$291.7 B \\
\hline 4 & Berkshire Hathaway & United States & $\$ 254.6 \mathrm{~B}$ & \$ $81.4 \mathrm{~B}$ & \$ 817.7 B & \$ 455.4 B \\
\hline 5 & Agricultural Bank of China & China & \$148.7 B & $\$ 30.9 \mathrm{~B}$ & $\$ 3,697.5 \mathrm{~B}$ & $\$ 147.2 \mathrm{~B}$ \\
\hline 5 & $\begin{array}{l}\text { Saudi Arabian Oil Company } \\
\text { (Saudi Aramco) }\end{array}$ & Saudi Arabia & $\$ 329.8 \mathrm{~B}$ & $\$ 88.2 \mathrm{~B}$ & \$ $398.3 \mathrm{~B}$ & $\$ 1,684.8 \mathrm{~B}$ \\
\hline 7 & Ping An Insurance Group & China & $\$ 155 \mathrm{~B}$ & $\$ 18.8 \mathrm{~B}$ & $\$ 1,218.6 \mathrm{~B}$ & \$187.2 B \\
\hline 8 & Bank of America & United States & \$ $112.1 \mathrm{~B}$ & \$24.1 B & $\$ 2,620 \mathrm{~B}$ & \$208.6 B \\
\hline 9 & Apple & United States & $\$ 267.7 \mathrm{~B}$ & $\$ 57.2 \mathrm{~B}$ & \$320.4 B & $\$ 1,285.5 \mathrm{~B}$ \\
\hline 10 & Bank of China & China & \$135.4 B & $\$ 27.2 \mathrm{~B}$ & $\$ 3,387 \mathrm{~B}$ & $\$ 112.8 \mathrm{~B}$ \\
\hline 11 & AT\&T & United States & $\$ 179.2 \mathrm{~B}$ & \$ $14.4 \mathrm{~B}$ & \$ 545.4 B & \$218.6 B \\
\hline 12 & Toyota Motor & Japan & $\$ 280.5 \mathrm{~B}$ & $\$ 22.7 \mathrm{~B}$ & $\$ 495.1 \mathrm{~B}$ & $\$ 173.3 \mathrm{~B}$ \\
\hline 13 & Alphabet & United States & \$166.3 B & $\$ 34.5 \mathrm{~B}$ & \$273.4 B & \$ $919.3 \mathrm{~B}$ \\
\hline 13 & ExxonMobil & United States & \$256 B & $\$ 14.3 \mathrm{~B}$ & $\$ 362.6 \mathrm{~B}$ & \$ $196.6 \mathrm{~B}$ \\
\hline 13 & Microsoft & United States & \$ $138.6 \mathrm{~B}$ & $\$ 46.3 \mathrm{~B}$ & \$285.4 B & $\$ 1,359 \mathrm{~B}$ \\
\hline
\end{tabular}

The worldwide pandemic caused by COVID-19 has hit the energy sector of the global economy hard. The massive 5.9\% decline in the energy demand throughout 2020 was the largest decline in energy consumption in the last 70 years. This decline is seven times greater than it was during the 2008 crisis (Global Energy Review, 2020).

As a result of such a decrease in energy demand, the global energy company PJSC Gazprom lost its positions in the rating, just like many other world oil and gas suppliers (including Valero Energy, Petrobras, Uniper). This happened due to the sharp drop in fuel prices, abnormally warm winter temperatures, the COVID-19 pandemic, the rupture of large contracts due to problems in the development of some deposits as a result of the sanctions against Russian companies introduced by a number of Western countries. Against this background, another trend stands out quite clearly: many insurance and investment companies, on the contrary, have strengthened their positions (Manulife Financial +237 lines, Prudential +292). This trend is rather obvious and somewhat predictable since due to the coronavirus pandemic the demand for life and health insurance has grown all over the world.

Having studied the leading ratings of giant companies, we can conclude that TNCs represent the most powerful part of the business operating on the international scale, playing 


\section{THE INFLUENCE OF TRANSNATIONAL CORPORATIONS}

a leading role in strengthening of the world economic ties, developing states, prospering science and technology, and establishing consumer behavior trends.

Now let us consider the contribution of the ratings leaders to the formation and development of the world economy.

Table 2 - Fortune Global 500: Q1 of 2020

(Source: Forbes Global, 2000)

\begin{tabular}{|c|l|c|c|c|c|c|}
\hline Rank & \multicolumn{1}{|c|}{ Company } & $\begin{array}{c}\text { Country / } \\
\text { Territory }\end{array}$ & Revenues & Profits & Assets & Employees \\
\hline 1 & Walmart & USA & $\$ 523.964 \mathrm{M}$ & $\$ 14.881 \mathrm{M}$ & $\$ 236.495 \mathrm{M}$ & $2,200,000$ \\
\hline 2 & Sinopec Group & China & $\$ 407,009 \mathrm{M}$ & $\$ 6,793.2 \mathrm{M}$ & $\$ 317,515.7 \mathrm{M}$ & 582,648 \\
\hline 3 & State Grid & China & $\$ 383.906 \mathrm{M}$ & $\$ 7.970 \mathrm{M}$ & $\$ 596,616.3 \mathrm{M}$ & 907,677 \\
\hline 4 & China National & China & $\$ 379,130 \mathrm{M}$ & $\$ 4,443.2 \mathrm{M}$ & $\$ 608,085.6 \mathrm{M}$ & $1,344,410$ \\
\hline 5 & Petroleum & UK & $\$ 352.106 \mathrm{M}$ & $\$ 15.842 \mathrm{M}$ & $\$ 404,336 \mathrm{M}$ & 83,000 \\
\hline 6 & Saudi Aramco & S, Arabia & $\$ 329.784 \mathrm{M}$ & $\$ 88,210.9 \mathrm{M}$ & $\$ 398,348.6 \mathrm{M}$ & 79,000 \\
\hline 7 & Volkswagen & Germany & $\$ 282,760 \mathrm{M}$ & $\$ 15,542 \mathrm{M}$ & $\$ 547,810.9 \mathrm{M}$ & 671.205 \\
\hline 8 & BP & UK & $\$ 282,616 \mathrm{M}$ & $\$ 4,026 \mathrm{M}$ & $\$ 295,194 \mathrm{M}$ & 72,500 \\
\hline 9 & Amazon.com & USA & $\$ 280,522 \mathrm{M}$ & $\$ 11,588 \mathrm{M}$ & $\$ 225,248 \mathrm{M}$ & 798,000 \\
\hline 10 & Toyota Motor & Japan & $\$ 275,288 \mathrm{M}$ & $\$ 19,096.2 \mathrm{M}$ & $\$ 487,465.9 \mathrm{M}$ & 359,542 \\
\hline 11 & ExxonMobil & USA & $\$ 264.938 \mathrm{M}$ & $\$ 14,340 \mathrm{M}$ & $\$ 362,597 \mathrm{M}$ & 74,900 \\
\hline 12 & Apple & USA & $\$ 260,174 \mathrm{M}$ & $\$ 55,256 \mathrm{M}$ & $\$ 338,516 \mathrm{M}$ & 137,000 \\
\hline 13 & CVS Health & USA & $\$ 256.776 \mathrm{M}$ & $\$ 6,634 \mathrm{M}$ & $\$ 222,449 \mathrm{M}$ & 290,000 \\
\hline 14 & Berkshire Hathaway & USA & $\$ 254,616 \mathrm{M}$ & $\$ 81,417 \mathrm{M}$ & $\$ 817,729 \mathrm{M}$ & 391,500 \\
\hline 15 & UnitedHealth Group & USA & $\$ 242,155 \mathrm{M}$ & $\$ 13.839 \mathrm{M}$ & $\$ 173,889 \mathrm{M}$ & 325,000 \\
\hline
\end{tabular}

The Industrial and Commercial Bank of China was founded back in 1984, and in 2005 it was transformed into a joint stock company with limited liability. In 2013, the ICBC entered the global list of systemically important banks. These are the institutions with key functions and global characteristics at the international financial market. If even one of such institutions suffers a major risk or an operational failure, this can have a significant impact on the global economic and financial system, up to systemic risks. As of the end of 2019, the Bank had 428 institutions in 48 countries of the world and indirectly covered 20 African countries as a shareholder of the Standard Bank Group. The Bank has done serious work on all aspects of the fight against poverty, namely, through increased lending to reduce poverty and improve integrated financial services provided to population (ICBC, 2020).

China Construction Bank (CCB) takes the second line in the Forbes 2000 rating. it was founded back in 1954 and since 2015 has been also among the globally systemically important banks. Adhering to the business concept of being "market-oriented, customeroriented", the Bank strives to achieve a balance between short-term and long-term benefits, as well as between its business goals and social responsibility, in order to maximize value for its stakeholders, including customers, shareholders, employees and the society overall. 
China today is ranked 1st in the world in terms of the size of the banking system. Chinese yuan has the status of a freely usable currency and is included in the SDR basket as the fifth currency, along with the US dollar, euro, Japanese yen and pound sterling. Moreover, in 2018, the PRC launched oil futures in yuan. This indicates the growing role of the country in the international financial sector. Some analysts point out to the fact that, in contrast to developed markets, China's regional authorities rely heavily on bank loans when financing their infrastructure projects. State-owned banks play the key role in this policy, including ICBC, CCB, ABC, and the Bank of China (Makarov, 2017).

JP Morgan Chase is one of the oldest and most influential financial conglomerates on the planet, operating in more than 100 countries and employing over 250,000 people. The experts from JP Morgan Chase financial holding regularly publish analytics and forecasts of the global economy, interact with non-profit organizations, clients, other financial institutions, multilateral organizations and other stakeholders to advance sustainable development efforts.

Apple Inc.is an American manufacturer of personal computers, mobile devices and computer software. It was Apple that released the famous Iphone, which has changed the world, many areas of activities and even whole professions. This smartphone has reached the peak of the immersion of human consciousness in the virtual worlds. Apple often sets trends for other manufacturers with its ideas and technological breakthroughs. The vibrant, competitive and booming app economy has sparked a real storm of innovation in 175 countries and has completely changed the way people learn, work and communicate around the world. The Apple App Store Ecosystem brought more than $\$ 519$ bln to the economy in 2019 alone (Ecosystem Apple, 2020).

Volkswagen AG is a German automotive concern consisting of 342 companies engaged in the production of automobiles and the related services. The Volkswagen concern has 123 plants across 20 European countries and 11 countries in North and South America, Asia and Africa, employing more than 650,000 people. The Volkswagen Group sells its vehicles in 153 countries around the world. The unique experience of the concern consists in carrying out a very correct personnel policy in the difficult times of economic crises: on the one hand, the company did not leave qualified employees unemployed, and on the other hand, did not deprive the company's owners of profits. In 2016, the Volkswagen Group adopted the TOGETHER - Strategy 2025, which implies huge changes aimed at transforming its core business and attracting new sources of income (Strategy of Volkswagen, 2020).

\section{Conclusions}

Despite the multitude of problems in the field of sustainable development of individual territories and entire countries, the management of all these companies is gradually beginning to realize the need to organize a business dialogue with various groups of stakeholders within national and foreign markets.

One of the key features of the world development today is the growing influence of globalization processes that stimulate the rapid growth of TNCs. Analyzing the above examples of the ratings leaders, we can say that the influence of TNCs on the development of the world economy, individual countries and entire continents can hardly be overestimated, since they have a tremendous resource potential. 


\section{THE INFLUENCE OF TRANSNATIONAL CORPORATIONS}

Nowadays multinational corporations recognize the importance of returning the moral criteria into the economic sphere, thus strengthening the socially responsible business behavior.

Based on the above, we can conclude that one of the key trends in the sustainable development of the world economy at the present stage is the recognition by economic agents of the importance and prospects of cooperation with ethically oriented business, the imperative of which is corporate social responsibility. Investments of TNC's foreign subsidiaries in the basic infrastructure, production facilities, social and environmental spheres of the territories of their presence should be considered from the viewpoint of corporate social responsibility. The contents and the volumes of financing of corporate social responsibility programs by foreign branches of TNCs are largely predetermined by the specificity of their business. Implementation of corporate social responsibility, which is always part of common business strategy, becomes an undeniable competitive advantage for TNCs over other companies.

\section{References:}

1. Bodienkova, V.S., Desyatnichenko, D. Yu. \& Kondyukova, E.S. (2017). Influence of transnational corporations on the world economy. Economic Relations, 3, 269-278.

2. Čech, L. (2011). Globalization and its influence on international political relations basic features of international political relations in the environment of a postmodern society of the globalizing world. Globalisation dimensions \& impacts: global studies series, 1, 29-48

3. China Construction Bank Corporation: Corporate Profile. Available online at: http://en.ccb.com/en/investorv3/corporateoverview/overview.html?ptId=1\&ctId=1.

4. Ecosystem Apple App Store (2019) Available online at: https://www.apple.com/ru/newsroom/2020/06/apples-app-store-ecosystem-facilitated-overhalf-a-trillion-dollars-in-commerce-in-2019/

5. Forbes Global 2000 (2020). Available online at: https://www.forbes.com/global2000/\#1a15ae21335d.

6. Global Energy Review 2020. (2020). The impacts of the Covid-19 crisis on global energy demand and CO2 emissions. Available online at: https://www.connaissancedesenergies.org/sites/default/files/pdfactualites/Global_Energy_Review_2020.pdf.

7. Global Risks 2020: An Unsettled World (2020). World Economic Forum. Available online at: https://reports.weforum.org/global-risks-report-2020/chapter-one-risks-landscape/.

8. ICBC Business Review (2020). Available online at: https://www.icbc.com.cn/ICBC/EN/AboutUs/BriefIntroduction/briefintroduction.htm.

9. Kościelniak, H., Łęgowik-Świącik, S. \& Jančíková, E. (2017). Business analytics of enterprises in terms of strategy. Polish Journal of Management Studies, 16 (1), 67-76.

10. Makarov, O. (2017). China's banking sector has become the world's largest. RBC Finances. Available online: https://www.rbc.ru/finances/06/03/2017/58bd3f469a7947e19a9034f9.

11. Popkova, E.G., Zolochevskaya, E.Y., Litvinova, S.A. \& Zima, Y.S. (2017). New Scenarios Of Joint Crises Fighting In Socio-Economic Sphere Of Russia And Greece. European Research Studies Journal, 20(1), 49-55. 
12. Strategy of Volkswagen Group Rus. Available online at: http://vwgroup.ru/career/kaluga/strategy/.

13. United Nations Industrial Development Organization (2020). Available online at: http://www.unido.ru/overview/mdg/.

14. Zolochevskaya, E.Yu., Cherkasova, T.P., Mishurina, O.V. \& Sivakova, Ya. E. (2018). Institutional Design In The System Of State Policy Measures For Stimulating Economic Growth In Russia In The Context Of Geopolitical Challenges. CBU International Conference Proceedings, 510-515.

Paper submitted

Paper accepted for publishing

Paper published online
07 January 2021

19 March 2021

31 March 2021 